\title{
A Thermostable Aspergillus fumigatus GH7 Endoglucanase Over-Expressed in Pichia pastoris Stimulates Lignocellulosic Biomass Hydrolysis
}

\author{
Aline Vianna Bernardi ${ }^{1}$, , Deborah Kimie Yonamine ${ }^{1}$, Sergio Akira Uyemura ${ }^{2}$ \\ and Taisa Magnani Dinamarco ${ }^{1, * \mathbb{D}}$ \\ 1 Faculty of Philosophy, Sciences and Literature of Ribeirão Preto, Chemistry Department, University of São \\ Paulo, Ribeirão Preto 14040-901, Brazil; alinevbernardi@gmail.com (A.V.B.); \\ deborah.yonamine@hotmail.com (D.K.Y.) \\ 2 Faculty of Pharmaceutical Science, Department of Clinical, Toxicological and Bromatological Analysis, \\ University of São Paulo, Ribeirão Preto 14040-903, Brazil; suyemura@fcfrp.usp.br \\ * Correspondence: tdinamarco@ffclrp.usp.br; Tel.: +55-16-3315-9121; Fax: +55-16-3315-9101
}

Received: 2 April 2019; Accepted: 5 May 2019; Published: 7 May 2019

check for updates

\begin{abstract}
In the context of avoiding the use of non-renewable energy sources, employing lignocellulosic biomass for ethanol production remains a challenge. Cellulases play an important role in this scenario: they are some of the most important industrial enzymes that can hydrolyze lignocellulose. This study aims to improve on the characterization of a thermostable Aspergillus fumigatus endo-1,4- $\beta$-glucanase GH7 (Af-EGL7). To this end, Af-EGL7 was successfully expressed in Pichia pastoris X-33. The kinetic parameters $K_{m}$ and $V_{m a x}$ were estimated and suggested a robust enzyme. The recombinant protein was highly stable within an extreme $\mathrm{pH}$ range (3.0-8.0) and was highly thermostable at $55^{\circ} \mathrm{C}$ for $72 \mathrm{~h}$. Low $\mathrm{Cu}^{2+}$ concentrations $(0.1-1.0 \mathrm{mM})$ stimulated Af-EGL7 activity up to $117 \%$. Af-EGL7 was tolerant to inhibition by products, such as glucose and cellobiose. Glucose at $50 \mathrm{mM}$ did not inhibit Af-EGL7 activity, whereas $50 \mathrm{mM}$ cellobiose inhibited Af-EGL7 activity by just $35 \%$. Additionally, the Celluclast ${ }^{\circledR} 1.5 \mathrm{~L}$ cocktail supplemented with Af-EGL7 provided improved hydrolysis of sugarcane bagasse "in natura", sugarcane exploded bagasse (SEB), corncob, rice straw, and bean straw. In conclusion, the novel characterization of Af-EGL7 conducted in this study highlights the extraordinary properties that make Af-EGL7 a promising candidate for industrial applications.
\end{abstract}

Keywords: Af-EGL7; GH7 endoglucanase; biomass hydrolysis; thermostability

\section{Introduction}

Raw material processing generates tons of agricultural and industrial waste every year. Unfortunately, biomass accumulation and misuse of such materials cause serious environmental issues. In addition, increased energy consumption, depletion of fossil fuel sources, and the need to abate global warming have drawn special attention to a new generation of renewable energy [1-3]. In this scenario, reusing lignocellulosic residues to synthesize chemical compounds and high-value products like biofuels and other green chemicals has emerged as one of the most potential strategies to overcome environmental problems $[2,4]$.

Lignocellulose consists mainly of cellulose (35-50\%), hemicellulose (20-30\%), and lignin (20-30\%) [5]. Cellulases produced by fungi and bacteria can degrade cellulose [6,7]. In fact, cellulases are considered to be some of the most important industrial enzymes as they can convert cellulose to sugars that can be further fermented to generate bioethanol and biobased products $[6,8,9]$. The classic mechanism of substrate degradation by cellulases involves the synergistic action of three types of 
hydrolytic enzymes: endo-1,4- $\beta$-glucanases (EC 3.2.1.4), cellobiohydrolases/exoglucanases (EC 3.2.1.91 and EC 3.2.1.176), and $\beta$-glucosidades (EC 3.2.1.21) [8,9].

Endo-1,4- $\beta$-glucanases catalyze the initial attack on the cellulose fibrils and randomly cleave the $\beta-1,4$-glycosidic bonds present in the amorphous regions of the cellulose chain. The other two cellulases then act to convert the oligosaccharides released from this hydrolysis into glucose [10,11]. According to the carbohydrate-active enzymes (CAZymes) database, endo-1,4- $\beta$-glucanases are widespread and are classified into 16 glycosyl hydrolase (GH) families. Enzymes belonging to the GH7 family can act on a broad range of substrates, including cellulose, $\beta$-glucan, lichenin, laminarin, and even xylan. This lack of specificity makes the endo-1,4- $\beta$-glucanases of this family very attractive for various industrial applications [9].

Because enzymes need to be exposed to extreme conditions during several industrial processes, stability to high temperatures within a wide $\mathrm{pH}$ range, as well as tolerance to inhibition by reaction products, are the most desired enzymatic properties at the industrial level $[9,12]$. Biomass saccharification at elevated temperatures reduces polysaccharides viscosity and bacterial contamination risks and allows enzymes to be directly used after steam pre-treatment, thereby shortening process duration and saving energy [11,13].

Aspergillus fumigatus, a thermophilic fungus, secretes several CAZymes that can be further used in enzymatic cocktails. Therefore, this fungus plays an important role in biomass deconstruction $[4,7,14]$. In our previous work, we expressed recombinant Af-EGL7 in E. coli and characterized its function [4]. Compared to the prokaryotic system, heterologous expression in the methylotrophic yeast P. pastoris offers many advantages, especially in terms of recombinant protein processing, folding, and post-translational modifications, which can influence enzyme functioning and even stability $[15,16]$.

This paper reports on the successful gene Af-egl7 cloning and expression in P. pastoris X-33 and on the characterization of the purified Af-EGL7. It shows that a recombinant GH7 endo-1,4- $\beta$-glucanase, with higher $\mathrm{pH}$ and thermal stabilities, is more active on complex biomasses. Our results highlight the industrial potential of the A. fumigatus recombinant endoglucanase Af-EGL7.

\section{Results and Discussion}

\subsection{Af-EGL7 Cloning and Expression}

Here, the CPEC method was used to amplify the endo- $1,4-\beta$-glucanase ORF (Open reading frame) Af-egl7 (Afu6g01800) from the A. fumigatus cDNA and to clone it into the expression vector $\mathrm{pPICZ} \alpha \mathrm{A}$ [17]. The recombinant vector $\mathrm{pPICZ} \alpha \mathrm{A} / A f-e g l 7$ was transformed into $E$. coli $\mathrm{DH} 10 \beta$ for plasmid propagation. Sequencing was performed to analyze possible mutations in the Af-egl7 sequence and to verify if the sequence had been cloned in frame with $\alpha$ factor signal peptide, which is important to obtain the recombinant enzyme extracellularly in the culture broth.

Next, the recombinant plasmid pPICZ $\alpha \mathrm{A} / A f-e g l 7$ was linearized with the restriction enzyme $P m e I$ to enable its integration into the $P$. pastoris $\mathrm{X}-33$ genome by homologous recombination, and transformed into this strain. After growth at $30^{\circ} \mathrm{C}$ for three days, positive transformants were selected with the Zeocin resistance marker. The 24 selected positive transformants were screened in solid medium containing $1 \%(w / v)$ CM-Cellulose as a substrate, and $1 \%(v / v)$ methanol for protein induction (Figure 1). After growth at $30^{\circ} \mathrm{C}$ for three days, the plates were stained with Congo Red and further de-stained with $\mathrm{NaCl}$ until pale orange zones appeared around the colonies. Degradation halos bigger than the control (ct, Pichia pastoris transformed with empty pPICZ $\alpha$ A vector) emerged around all the tested colonies, except for number 4 . This indicated expression of a functional enzyme that can degrade CM-Cellulose. Colony PCR also confirmed positive transformants. 

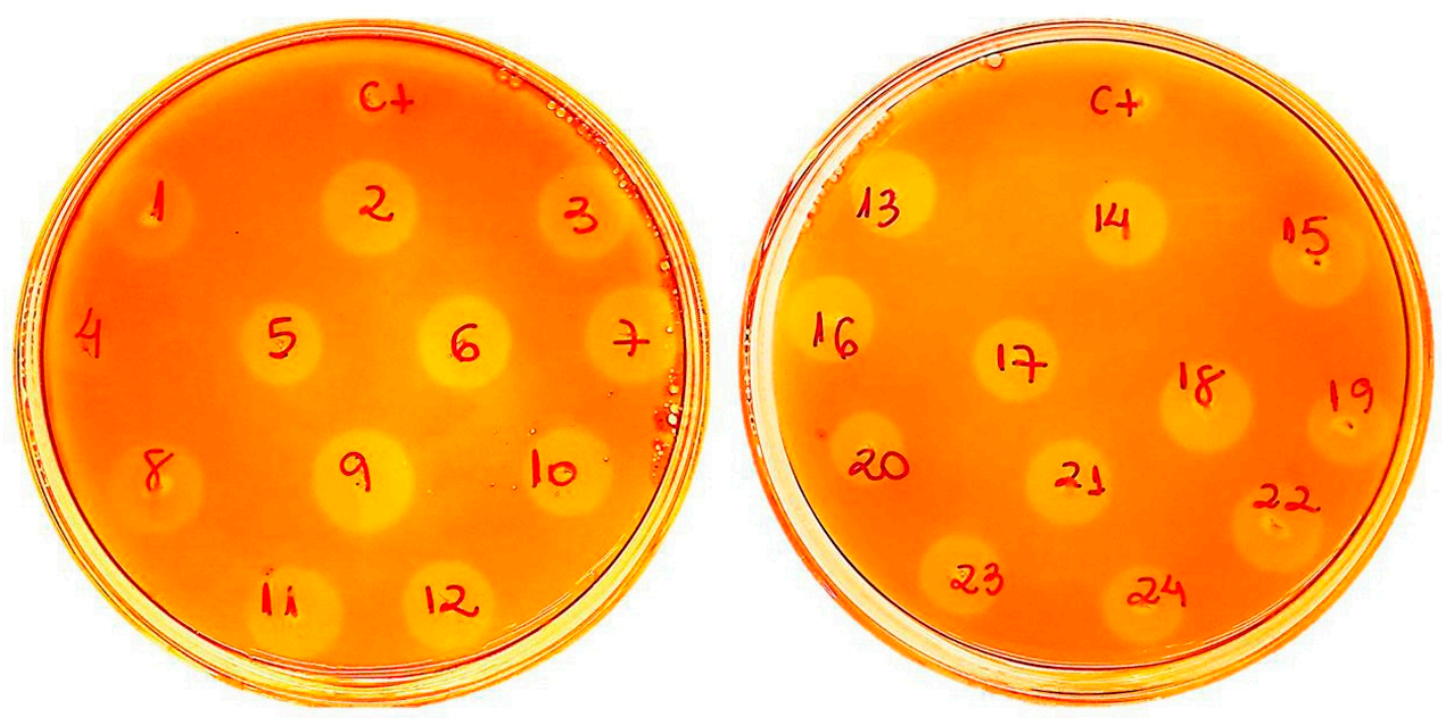

Figure 1. Screening of Af-EGL7 activity in 24 Pichia pastoris transformants on 1\% (w/v) CM-Cellulose plate after heterologous expression induction with $1 \%(v / v)$ methanol. The host transformed with empty vector was used as control (ct). Pale orange halos bigger than the control indicated the positive functional colonies.

\subsection{Af-EGL7 Expression and Purification}

For this study, a positive P. pastoris X-33 transformant was selected, and Af-EGL7 was successfully expressed under control of the AOX-1 promoter after induction with $1.5 \%(v / v)$ methanol for six days. The culture supernatant was harvested by centrifugation and concentrated by tenfold before Af-EGL7 was purified by $\mathrm{Ni}^{2+}$-nitrilotriacetic (Ni-NTA) affinity chromatography. During protein elution, all fractions were collected and analyzed by SDS-PAGE (Figure 2a). Af-EGL7 eluted from $20 \mathrm{mM}$ imidazole in greater amounts, but the fraction eluted with $80 \mathrm{mM}$ imidazole had higher purity. All the fractions were combined, and the pure protein concentration estimated by the Greenberg method [18] was $450 \mu \mathrm{g}$ protein. $\mathrm{mL}^{-1}$.

A previous study had indicated that the Af-EGL7 molecular weight is $48 \mathrm{kDa}$. However, the Af-EGL7 molecular weight estimated by SDS-PAGE herein was approximately $70 \mathrm{kDa}$. This difference suggested the presence of $\mathrm{N}$-glycans in the Af-EGL7 structure, which agreed with the analysis performed by NetGlyc 1.0 Server (http://www.cbs.dtu.dk/services/NetNGlyc/) predicting four potential $\mathrm{N}$-glycosylation sites in the Af-EGL7 structure, at the N96, N201, N205, and N379 residues [4].

Af-EGL7 treatment with Endoglycosidase H produced a protein with a molecular weight of approximately $60 \mathrm{kDa}$ (Figure 2b). However, the molecular mass was still higher than the theoretical value even after deglycosylation. This difference could be due to protein hyperglycosylation, which is common in P. pastoris heterologous proteins, and to O-glycosylations, which usually occur in GH7 enzymes $[19,20]$. 
(a)

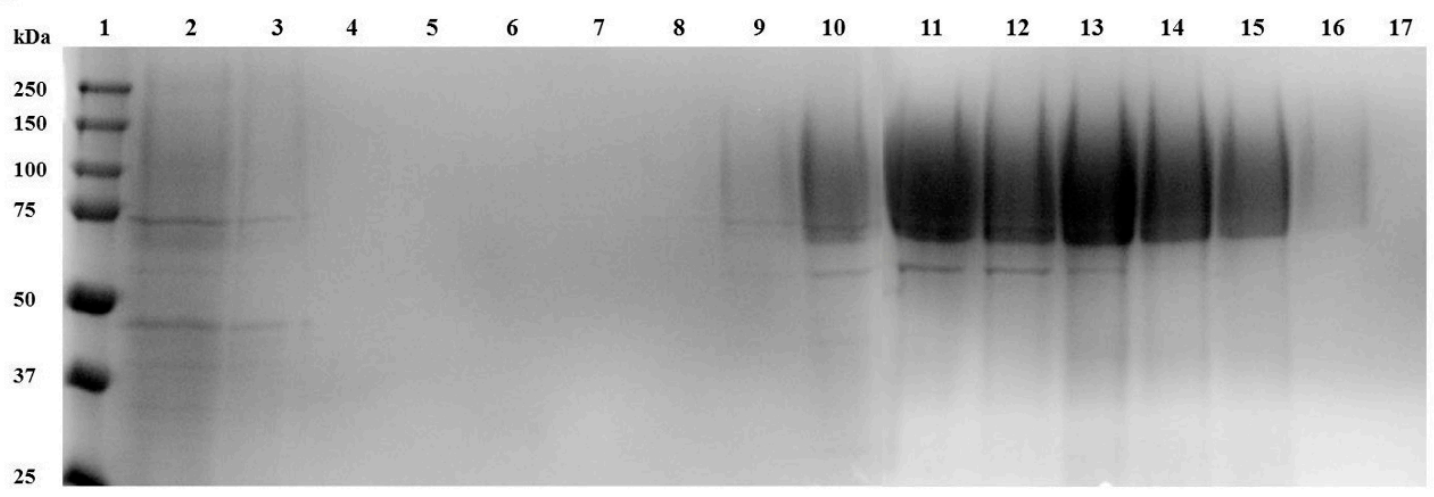

(b)

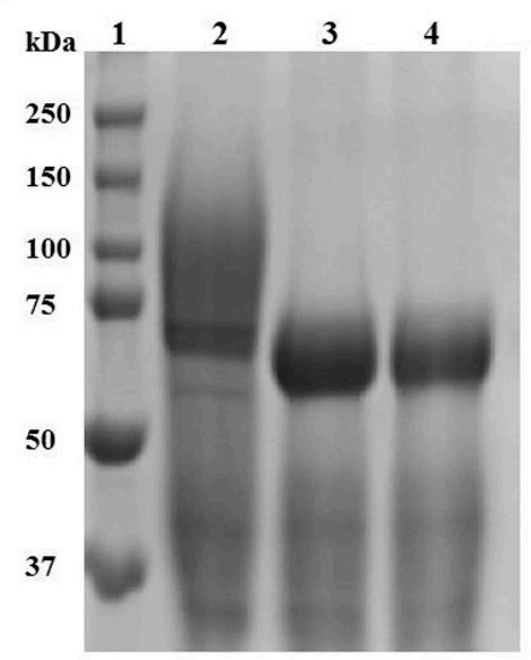

Figure 2. SDS-PAGE electrophoresis to evaluate (a) Af-EGL7 expression and purification. Lane 1: Molecular weight marker (Precision ${ }^{\mathrm{TM}}$ Protein Standards Dual Color; BioRad, Hercules, CA, USA). Lane 2: Flow-through. Lanes 3-7: Fractions obtained after elution with $0 \mathrm{mM}$ imidazole. Lanes 8-17: Fractions obtained after elution with 5, 10, 20, 40, 40, 80, 80, 160, 250, and $500 \mathrm{mM}$ imidazole. (b) Af-EGL7 deglycosylation. Lane 1: Molecular weight marker (Precision ${ }^{\mathrm{TM}}$ Protein Standards Dual Color; BioRad). Lane 2: Untreated purified Af-EGL7. The target protein is located with an estimated mass of $70 \mathrm{kDa}$. Lane 3 and 4: Af-EGL7 after Endo $\mathrm{H}$ treatment under non-denaturing and denaturing conditions, respectively. Both deglycosilation reactions produced a purified protein with approximately $60 \mathrm{kDa}$.

\subsection{Biochemical Characterization}

\subsubsection{Enzyme Activity}

In a previous work, our group characterized recombinant Af-EGL7 expressed in E. coli and found that this enzyme displays optimal activity at $55^{\circ} \mathrm{C}$ and $\mathrm{pH} 5.0$ [4]. Here, recombinant Af-EGL7 expressed in P. pastoris also presented optimal activity under these same conditions.

In the present work, the Af-EGL7 $\mathrm{V}_{\max }, \mathrm{K}_{M}$, and $\mathrm{k}_{\text {cat }}$ kinetic parameters were determined at $55^{\circ} \mathrm{C}$ by using CM-Cellulose, $\beta$-glucan, or Xyloglucan as substrates (Table 1). Af-EGL7 exhibited much higher activity in medium-viscosity barley $\beta$-glucan than in low-viscosity CM-Cellulose. This is an intrinsic feature of most GH7 endoglucanases and may be due to the high number of methoxy side chains substituting the CM-Cellulose, which can interfere in enzyme action. It also suggests that Af-EGL7 can hydrolyze both $\beta-1,4-$ and $\beta-1,3-$ glycosydic linkages $[4,9]$. 
Table 1. Af-EGL7 kinetic parameters.

\begin{tabular}{|c|c|c|c|c|}
\hline Substrate & $\mathrm{K}_{M}\left(\mathrm{mg} \cdot \mathrm{mL}^{-1}\right)$ & $\mathrm{V}_{\max }\left(\mu \mathrm{mol} \cdot \mathrm{min}^{-1} \cdot \mathrm{mg}^{-1}\right)$ & $\mathbf{k}_{\text {cat }}\left(\mathrm{s}^{-1}\right)$ & $\mathrm{k}_{\text {cat }} / \mathrm{K}_{M}\left(\mathrm{~mL} \cdot \mathrm{mg}^{-1} \cdot \mathrm{s}^{-1}\right)$ \\
\hline CM-Cellulose & $24.5 \pm 0.6$ & $6193 \pm 140$ & $5037 \pm 114$ & $205.9 \pm 0.8$ \\
\hline$\beta$-glucan & $5.6 \pm 0.3$ & $13722 \pm 519$ & $11161 \pm 422$ & $1992 \pm 37$ \\
\hline Xyloglucan & $8.6 \pm 0.3$ & $9082 \pm 293$ & $7386 \pm 238$ & $859.9 \pm 0.2$ \\
\hline
\end{tabular}

Comparison of these kinetic parameters with those previously reported for the recombinant Af-EGL7 expressed in E. coli [4] revealed high Af-EGL7 catalytic efficiency after its expression in $P$. pastoris, which probably resulted from correct enzyme processing in the eukaryotic strain. The $\mathrm{k}_{c a t} / \mathrm{K}_{M}$ values in CM-Cellulose and $\beta$-glucan calculated for the recombinant Af-EGL7 expressed in P. pastoris were 995- and 1419-fold higher than the respective values obtained for the recombinant Af-EGL7 expressed in E. coli, respectively.

Furthermore, Af-EGL7 presented higher $\mathrm{V}_{\max }$ values than most endoglucanases described to date. Actually, the Cel7A $\mathrm{V}_{\max }$ is $5000 \pm 186 \mu \mathrm{mol} \cdot \mathrm{min}^{-1} \cdot \mathrm{mg}^{-1}$ in the substrate barley $\beta$-glucan [9]. Hua and collaborators estimated a $\mathrm{V}_{\max }$ of $12.60 \pm 0.64 \mu \mathrm{g} \cdot \mathrm{min}^{-1} \cdot \mathrm{mL}^{-1}$ for Ctendo7 in this same substrate [5]. The $\mathrm{V}_{\max }$ values reported for Egl7A and $\mathrm{MtEg7A}$ in CMC are $2257 \pm 79$ and $622.5 \pm 86.4 \mu \mathrm{mol} \cdot \mathrm{min}^{-1} \cdot \mathrm{mg}^{-1}$, respectively, while the estimated value for an A. terreus $\mathrm{GH} 12$ endoglucanase is $16.15 \mu \mathrm{mol} \cdot \mathrm{min}^{-1} \cdot \mathrm{mg}^{-1}[11,21,22]$.

The effect of different ions and metals on recombinant Af-EGL7 expressed in P. pastoris was also tested herein. The same effect described by Bernardi et al. (2018) occurred [4]. However, considering the important role played by $\mathrm{Cu}^{2+}$ in lytic polyssacharide monooxygenase (LPMO) activity and the synergistic effect that LPMO and endoglucanases have on biomass hydrolysis, Af-EGL7 activity was also assessed at different $\mathrm{Cu}^{2+}$ concentrations (Table 2) [23].

Table 2. Effect of different $\mathrm{Cu}^{2+}$ concentrations on Af-EGL7 activity.

\begin{tabular}{cc}
\hline $\mathrm{Cu}^{2+}$ Concentration $(\mathbf{m M})$ & Af-EGL7 Relative Activity (\%) \\
\hline $\mathbf{0 . 0}$ & $100.0 \pm 1.7$ \\
$\mathbf{0 . 1}$ & $107.2 \pm 1.4$ \\
$\mathbf{0 . 5}$ & $115.5 \pm 0.5$ \\
$\mathbf{1 . 0}$ & $117.4 \pm 0.7$ \\
$\mathbf{5 . 0}$ & $85.9 \pm 1.5$ \\
$\mathbf{1 0 . 0}$ & $49.8 \pm 1.5$ \\
$\mathbf{1 5 . 0}$ & $21.7 \pm 0.3$ \\
\hline
\end{tabular}

Af-EGL7 activity increased at low $\mathrm{Cu}^{2+}$ concentrations (0.1-1.0 mM). Addition of 5, 10 and $15 \mathrm{mM}$ $\mathrm{Cu}^{2+}$ partially reduced Af-EGL7 activity to $85 \%, 49 \%$, and $21 \%$, respectively. These results showed that the association of Af-EGL7 with LPMOs (copper-dependent enzymes) in an enzymatic cocktail is possible, which could enhance cellulose hydrolysis.

\subsubsection{Enzyme Stability}

CAZymes (carbohydrate-active enzymes) glycosylation has been associated with higher enzyme thermal stability during natural and industrial processes, cellulose hydrolysis or binding, and protection from proteolysis $[20,24]$. In this sense, herein Af-EGL7 thermal stability was evaluated by pre-incubating the enzyme at different temperatures $\left(55,60,70,80\right.$ and $\left.90^{\circ} \mathrm{C}\right)$ for different time intervals.

At $55^{\circ} \mathrm{C}$, the enzyme did not lose activity after incubation for $72 \mathrm{~h}$. However, the enzyme started to lose activity at higher temperatures and retained $61 \%$ of its maximal activity after $24 \mathrm{~h}$ at $60^{\circ} \mathrm{C}$. After one hour at more extreme temperatures such as 70,80 and $90^{\circ} \mathrm{C}$, the residual activities were $75 \%, 60 \%$ and $32 \%$, respectively (Figure $3 a$ ). 
(a)

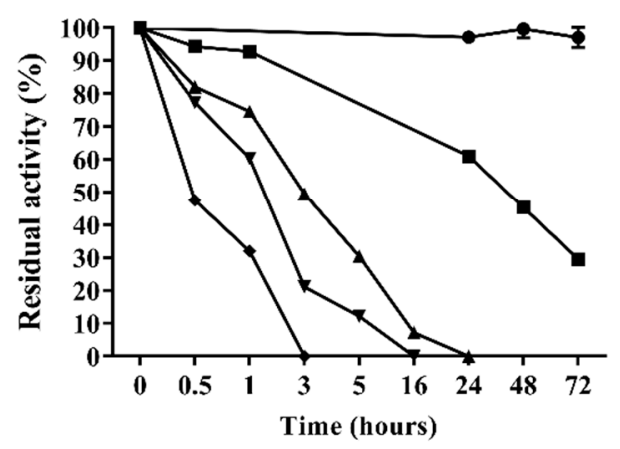

(b)

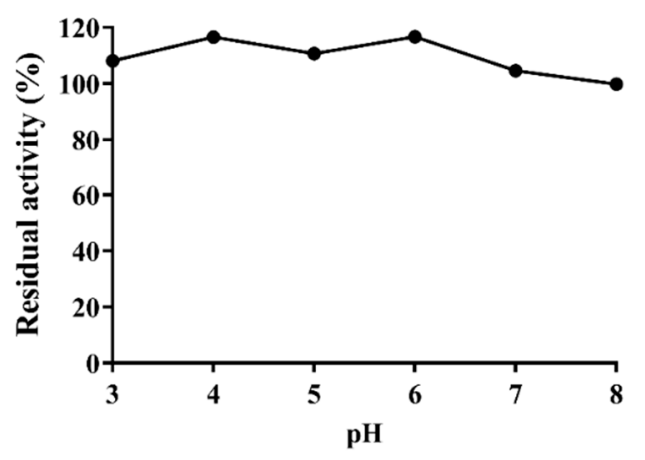

Figure 3. Plots of Af-EGL7 residual activity against incubation time at different temperatures and $\mathrm{pH}$. (a) Af-EGL7 stability at $\bullet 55^{\circ} \mathrm{C}, \boldsymbol{\square} 60^{\circ} \mathrm{C}, \boldsymbol{\Delta} 70^{\circ} \mathrm{C}, \boldsymbol{\nabla} 80^{\circ} \mathrm{C}$, and $\bullet 0^{\circ} \mathrm{C}$. (b) Af-EGL7 stability in the pH range 3.0-8.0. Error bars represent standard deviation $(n=3)$.

The comparatively high temperature stability of the enzyme obtained here was surprising. When Af-EGL7 was expressed in E. coli, stability at these temperatures decreased rapidly, and residual activity was absent after $30 \mathrm{~min}$ at $60-90^{\circ} \mathrm{C}$ [4]. Again, the better thermal stability observed in the present study was probably due to enzyme processing during its expression in P. pastoris, including post-translational modifications like glycosylation $[15,16]$.

Cellulases from thermophilic microorganisms have commonly been described as having a high thermostability $[25,26]$. The endoglucanases $M t E G 7 a$ and Ctendo7 from the thermophilic fungi $M$. thermophila and C. thermophilum displayed about $40 \%$ and $60 \%$ residual activity after eight and one hour at $80^{\circ} \mathrm{C}$, respectively [5,11]. Egl7A and Cel7A from T. emersonii and $N$. fisheri retained more than $40 \%$ and $16 \%$ of their maximal activity after they were incubated at $70{ }^{\circ} \mathrm{C}$ for $1 \mathrm{~h}[9,27]$ (Table 3).

Our results revealed that Af-EGL7 was remarkably thermostable and withstood high temperatures even in the absence of a substrate. In fact, Af-EGL7 exhibited higher thermal stability than many previously reported thermostable glucanases. Given the numerous advantages of carrying out processes at temperatures above $50^{\circ} \mathrm{C}$, thermostability is one of the most desirable enzymatic properties in the industry $[13,28,29]$. Steam pre-treatment has been the most frequently employed treatment to make biomass suitable for enzymatic saccharification. Thermostable enzymes can be directly used after this heating step, saving time, expenses, and as well as providing better reaction yields [11,29-31].

Considering the broad range of biotechnological applications that $\beta$-glucanases have, great attention has also been directed to obtaining enzymes that are stable over a wide range of $\mathrm{pH}$ values. Alkaline-stable cellulases can be primarily applied as additives in washing powder and detergents. Cellulases that are stable under mild conditions ( $\mathrm{pH}$ 5.0-6.0) can be used in brewing and biofuel production processes $[4,11,32]$. Acidophilic and acid-stable enzymes are favorable for application in the food and textile industries [16,32]. For this reason, here Af-EGL7 stability was evaluated at a pH ranging from 3.0 to 8.0. The recombinant enzyme was remarkably stable in both acidic and alkaline conditions (Figure 3b).

Analysis of the $\mathrm{pH}$ stability after incubation for $72 \mathrm{~h}$ did not show any Af-EGL7 activity loss. On the basis of these results, Af-EGL7 exhibited higher pH stability as compared to all the GH7 described so far, for which $\mathrm{pH}$ stability was only detected after shorter incubation intervals, as described in Table 3. Therefore, Af-EGL7 can be used in industrial processes over a broad $\mathrm{pH}$ range and for long incubation times. 
Table 3. Comparison among the catalytic and stability properties of GH7 endoglucanases from different organisms.

\begin{tabular}{|c|c|c|c|c|c|c|c|c|}
\hline Source Organism & $\begin{array}{l}\text { Expression } \\
\text { System }\end{array}$ & Substrate & $\mathrm{V}_{\max }\left(\mathrm{U} \cdot \mathrm{mg}^{-1}\right)$ & $\mathrm{K}_{M}\left(\mathrm{mg} \cdot \mathrm{mL}^{-1}\right)$ & $\mathrm{kcat}\left(\mathrm{s}^{-1}\right)$ & $\begin{array}{c}\mathbf{k c a t} / \mathrm{K}_{M} \\
\left(\mathrm{~mL} \cdot \mathrm{mg}^{-1} \cdot \mathrm{s}^{-1}\right)\end{array}$ & Thermal Stability & pH Stability \\
\hline \multirow{3}{*}{$\begin{array}{l}\text { Aspergillus fumigatus } \\
\text { (this work) }\end{array}$} & \multirow{3}{*}{ Pichia pastoris } & $\beta$-Glucan & $13722 \pm 519$ & $5.6 \pm 0.3$ & $11161 \pm 422$ & $1992 \pm 37$ & \multirow{3}{*}{$\begin{array}{c}100 \% \text { after } 72 \mathrm{~h} \text { at } 55^{\circ} \mathrm{C} ; 30 \% \\
\text { after } 1 \mathrm{~h} \text { at } 90^{\circ} \mathrm{C}\end{array}$} & \multirow{3}{*}{$\begin{array}{l}\text { No loss after } 72 \mathrm{~h} \text { in the } \mathrm{pH} \text { range } \\
\qquad 3.0-8.0\end{array}$} \\
\hline & & Xyloglucan & $9082 \pm 293$ & $8.6 \pm 0.3$ & $7386 \pm 238$ & $859.9 \pm 0.2$ & & \\
\hline & & CMC-Na & $6193 \pm 140$ & $24.5 \pm 0.6$ & $5037 \pm 114$ & $205.9 \pm 0.8$ & & \\
\hline \multirow{2}{*}{$\begin{array}{c}\text { Aspergillus fumigatus } \\
{[4]}\end{array}$} & \multirow{2}{*}{ Escherichia coli } & $\beta$-Glucan & $191.9 \pm 0.0007$ & $113.9 \pm 0.005$ & 159.9 & 1.4 & \multirow{2}{*}{$\begin{array}{l}85 \% \text { after } 48 \text { h at } 50{ }^{\circ} \mathrm{C} ; 40 \% \\
\text { after } 1 \mathrm{~h} \text { at } 55^{\circ} \mathrm{C}\end{array}$} & \multirow{2}{*}{ Start to decrease after $24 \mathrm{~h}$ at $\mathrm{pH} 6.0$} \\
\hline & & CMC-Na & $51.9 \pm 0.007$ & $209.7 \pm 0.1$ & 43.3 & 0.2 & & \\
\hline $\begin{array}{c}\text { Neosartorya fischeri } \\
{[9]}\end{array}$ & Pichia pastoris & $\beta$-Glucan & $5000 \pm 186$ & $4.5 \pm 0.2$ & - & - & $16.1 \%$ after $1 \mathrm{~h}$ at $70^{\circ} \mathrm{C}$ & $\begin{array}{l}\text { No loss after } 1 \mathrm{~h} \text { in the } \mathrm{pH} \text { range } \\
3.0-8.0\end{array}$ \\
\hline \multirow{2}{*}{$\begin{array}{c}\text { Talaromyces } \\
\text { emersonii [27] }\end{array}$} & \multirow{2}{*}{ Pichia pastoris } & $\beta$-Glucan & $17951 \pm 69$ & $4.0 \pm 1.5$ & - & $3156 \pm 24$ & \multirow{2}{*}{$\begin{array}{l}\text { More than } 50 \% \text { after } 2 \text { min at } \\
80^{\circ} \mathrm{C}\end{array}$} & \multirow{2}{*}{$\begin{array}{l}\text { More than } 70 \% \text { and } 50 \% \text { after } 1 \mathrm{~h} \text { in } \\
\text { the pH range } 1.0-11.0 \text { and at } \mathrm{pH} 12.0 \\
\text { respectively }\end{array}$} \\
\hline & & CMC-Na & $2257 \pm 79$ & $20.8 \pm 2.1$ & - & $78.9 \pm 3.8$ & & \\
\hline $\begin{array}{l}\text { Myceliophthora } \\
\text { thermophile [11] }\end{array}$ & Pichia pastoris & CMC-Na & $622.5 \pm 86.4$ & $24.0 \pm 0.5$ & - & 0.313667 & $\begin{array}{c}\mathrm{t}_{1 / 2}=9.96 \mathrm{~h}\left(70^{\circ} \mathrm{C}\right) ; \mathrm{t}_{1 / 2}=6.5 \mathrm{~h} \\
\left(80^{\circ} \mathrm{C}\right)\end{array}$ & $\begin{array}{l}\text { No loss after } 24 \mathrm{~h} \text { in the } \mathrm{pH} \text { range } \\
3.0-11.0\end{array}$ \\
\hline $\begin{array}{c}\text { Trichoderma } \\
\text { harzianum [12] }\end{array}$ & Aspergillus niger & Xyloglucan & $\begin{array}{l}0.22 \pm 0.095 \\
\left(\mu \mathrm{M} \cdot \mathrm{s}^{-1}\right)\end{array}$ & $1.98 \pm 0.47$ & 0.45 & - & $\begin{array}{c}100 \% \text { after two months of } \\
\text { incubation at } 55^{\circ} \mathrm{C} \text { and pH } 5.0\end{array}$ & - \\
\hline \multirow{2}{*}{$\begin{array}{c}\text { Chaetomium } \\
\text { thermophilum [5] }\end{array}$} & \multirow{2}{*}{ Pichia pastoris } & CMC-Na & $59.6 \pm 8.2$ & $79.2 \pm 5.8$ & $2.11 \times 10^{-3}$ & 0.02673 & \multirow{2}{*}{$\begin{array}{l}61.3 \% \text { after } 60 \mathrm{~min} \text { at } 80^{\circ} \mathrm{C} \\
\text { Almost all activity lost after } \\
100 \text { min at } 90^{\circ} \mathrm{C}\end{array}$} & \multirow[t]{2}{*}{-} \\
\hline & & $\beta$-Glucan & $\begin{array}{c}12.6 \pm 0.6 \\
\left(\mu \mathrm{g} \cdot \mathrm{min}^{-1} \cdot \mathrm{mL}^{-1}\right)\end{array}$ & $9.8 \pm 0.6$ & $0.7 \times 10^{-3}$ & 0.07849 & & \\
\hline \multirow{2}{*}{$\begin{array}{c}\text { Bispora sp. MEY-1 } \\
\text { [33] }\end{array}$} & \multirow{2}{*}{ Pichia pastoris } & $\beta$-glucan & 6737 & 9.16 & - & - & \multirow{2}{*}{$\begin{array}{l}100 \% \text { after } 1 \mathrm{~h} \text { at } 60^{\circ} \mathrm{C} \text {; More } \\
\text { than } 30 \% \text { after } 1 \mathrm{~h} \text { at } 70{ }^{\circ} \mathrm{C}\end{array}$} & \multirow{2}{*}{$\begin{array}{l}\text { More than } 85 \% \text { after } 1 \mathrm{~h} \text { in the } \mathrm{pH} \\
\text { range } 1.0-8.0\end{array}$} \\
\hline & & CMC-Na & 3460 & 287 & - & - & & \\
\hline
\end{tabular}




\subsubsection{Af-EGL7 Tolerance to Product Inhibition}

Cellobiose and glucose accumulation is one of the factors that limit biomass hydrolysis the most because it reduces enzyme catalytic efficiency and may increase process costs [34-36].

Previously, we described Af-EGL7 activity in xyloglucan [4]. The xyloglucan backbone resembles a cellulose chain: it consists of D-glucan $(\beta 1 \rightarrow 4)$ substituted with xylose sidechains, which allows the products' inhibitory effect on Af-EGL7 cellulase activity to be evaluated with precision [32]. In this sense, the effect of different glucose and cellobiose concentrations on Af-EGL activity was evaluated herein by using the chromogenic substrate Azo-Xyloglucan from Tamarind.

Addition of glucose did not affect Af-EGL7 and even enhanced its activity at concentrations higher than $25 \mathrm{mM}$ (Figure 4a). Moreover, $10 \mathrm{mM}$ and $25 \mathrm{mM}$ cellobiose inhibited Af-EGL7 activity by $14 \%$ and $23 \%$, respectively. At the highest concentration of this effector $(50 \mathrm{mM})$, residual activity corresponded to $65 \%$ (Figure $4 \mathrm{~b}$ ). Similar results were observed for the GH5 endoglucanase Egst: $30 \mathrm{mM}$ glucose stimulated its activity by 1.6-fold, whereas $50 \mathrm{mM}$ cellobiose inhibited its activity by about $33 \%$ [34].

(a)

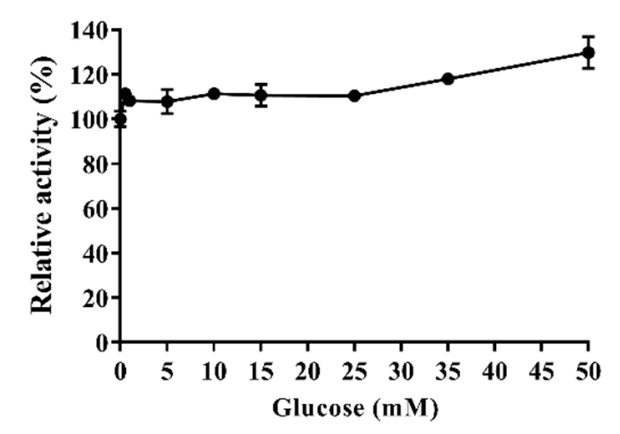

(b)

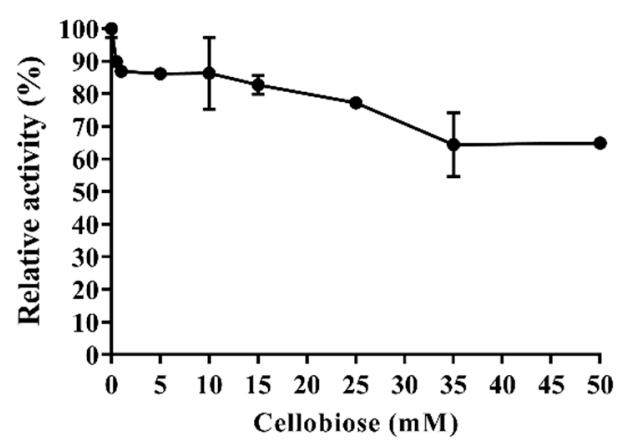

Figure 4. Glucose (a) and cellobiose (b) effect on Af-EGL7 activity. Error bars represent the standard deviation $(n=3)$.

These characteristics are highly important and desirable for the application of enzymes during biomass hydrolysis and make Af-EGL7 an enzyme of great commercial interest.

\subsection{Enzyme Performance in Agroindustrial Residue Degradation}

To analyze the enzyme performance in biomass degradation, $1 \%$ of sugarcane bagasse "in natura", sugarcane exploded bagasse (SEB), rice straw, corncob, barley bagasse or bean straw was added to 0.009 FPU of cellulase cocktail (Celluclast ${ }^{\circledR} 1.5 \mathrm{~L}$ ) and $10 \mu \mathrm{g}$ of thermostable Af-EGL7 and incubated at $55^{\circ} \mathrm{C}$ and $1000 \mathrm{rpm}$ for 24,48 , or $72 \mathrm{~h}$. Interestingly, this enzyme showed a high degree of synergy with the cocktail in the deconstruction of all the tested substrates, except barley bagasse (Figure 5).

Af-EGL7 greatly enhanced the release of reducing sugars over the incubation time. Af-EGL7 synergy was higher in corncob and rice straw as substrates, which increased the amount of released reducing sugars by $128 \%$ and $80 \%$ after $72 \mathrm{~h}$, respectively, as compared to cocktail alone.

Interesting facts were observed during SEB and sugarcane bagasse "in natura" hydrolysis. Surprisingly, when SEB hydrolysis was performed with the recombinant enzyme alone, released reducing sugars reached up to $1.3 \% \pm 0.07$ after $72 \mathrm{~h}$ Besides that, the cocktail hydrolyzed both SEB and sugarcane bagasse "in natura", which had their conversion enhanced by Af-EGL7 at a similar rate (40-45\%) after 72 and $48 \mathrm{~h}$ of reaction, respectively. 
(a) Sugarcane bagasse "in natura"

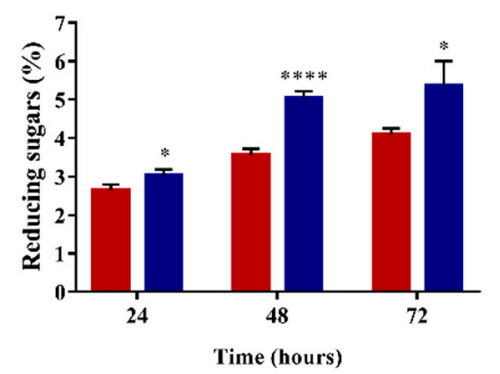

(c)

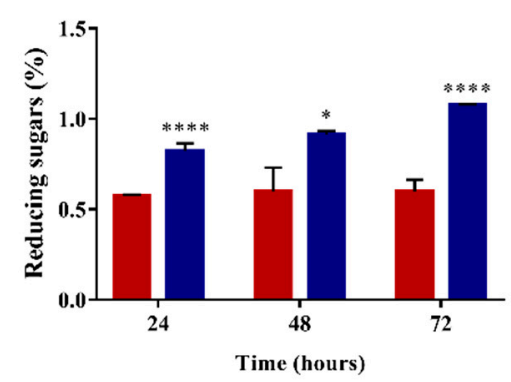

(e)

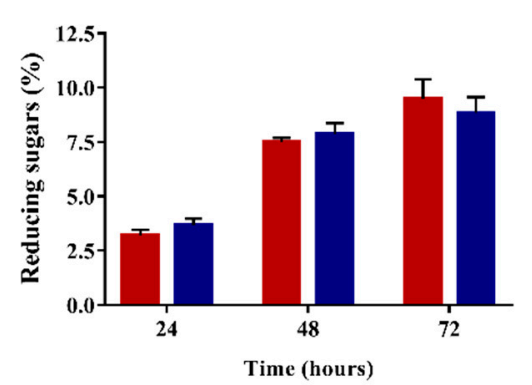

(b)

SEB

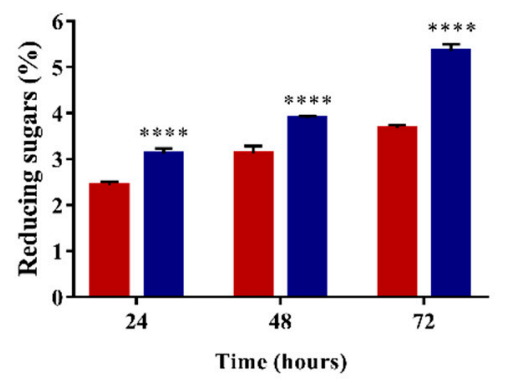

(d)

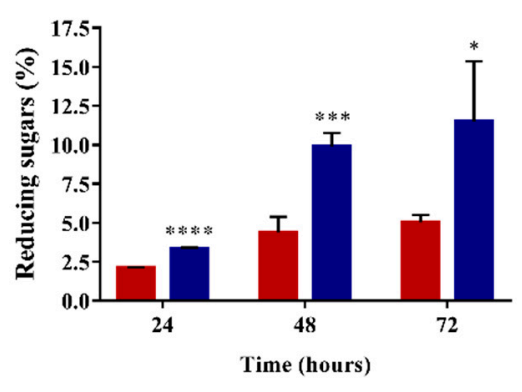

(f)

Bean Straw

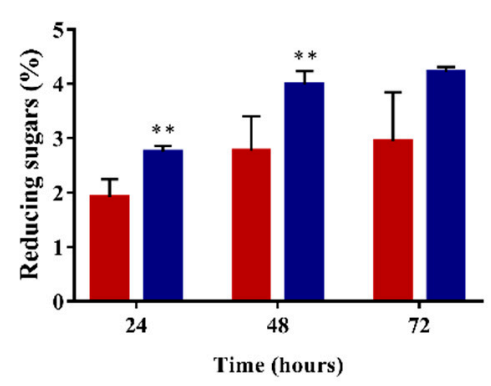

Figure 5. Effect of the cellulase cocktail Celluclast ${ }^{\circledR} 1.5 \mathrm{~L}$ (Red box) and supplemented by the addition of Af-EGL7 (Blue box), during hydrolysis of the agricultural residues (a) Sugarcane bagasse "in natura", (b) SEB, (c) Rice straw, (d) Corn cob, (e) Barley bagasse and (f) Bean straw. The data represent means \pm standard errors obtained from at least three experimental replicates.

Finally, our data showed that Af-EGL7 was able to improve the hydrolysis of most of the evaluated agricultural residues, which have different compositions (Table S1, [37-40]), revealing a significant enzymatic potential for the industry in terms of efficiency and economy.

\section{Materials and Methods}

\subsection{Strains, Culture Conditions and Vector}

Aspergillus fumigatus Af293, kindly donated by Prof. Dr. Sérgio Akira Uyemura (University of São Paulo, Ribeirão Preto, Brazil), was grown in yeast extract-agar-glucose (YAG) medium $(2.0 \%(w / v)$ dextrose, $2.0 \%(w / v)$ agar, $0.5 \%(w / v)$ yeast extract, and $0.1 \%(v / v)$ trace elements) at $37^{\circ} \mathrm{C}$ for two days to obtain a fresh conidium suspension. The conidia were inoculated to a final concentration of $2 \times 10^{6}$ per $\mathrm{mL}$ of YNB minimal medium ( $1 \times$ salts solution, $0.1 \%(v / v)$ trace elements, and $0.05 \%(w / v)$ yeast extract) containing $1 \%(w / v)$ fructose and incubated at $37^{\circ} \mathrm{C}$ and under shaking at $200 \mathrm{rpm}$ for $16 \mathrm{~h}$. Next, the mycelia were harvested, washed, and transferred to YNB medium containing $1 \%(w / v)$ 
sugarcane exploded bagasse (SEB) at $37^{\circ} \mathrm{C}$ and $200 \mathrm{rpm}$ for $24 \mathrm{~h}$. Then, the mycelia were harvested for RNA extraction.

The plasmid pPICZ $\alpha$ A (Invitrogen, Carlsbad, CA, USA) was used for gene cloning, sequencing, and expression. Escherichia coli $\mathrm{DH} 10 \beta$ grown at $37{ }^{\circ} \mathrm{C}$ and $200 \mathrm{rpm}$ in low salt Luria-Bertani medium supplemented with zeocin $\left(50 \mu \mathrm{g} \cdot \mathrm{mL}^{-1}\right)$ was used to propagate the recombinant vector pPICZ $\alpha \mathrm{A} / A f-e g l 7$. Pichia pastoris strain X-33 (Invitrogen, Carlsbad, CA, USA) cells harboring the recombinant expression vector $\mathrm{pPICZ} \alpha \mathrm{A} / A f-e g l 7$ were used to produce heterologous protein. The employed growth conditions are described in the EasySelect ${ }^{\mathrm{TM}}$ Pichia Expression Kit manual (Invitrogen, Carlsbad, CA, USA).

The low-viscosity substrate CM-Cellulose was purchased from Sigma (Sigma-Aldrich, St. Louis, MO, USA). Medium-viscosity Barley $\beta$-glucan and Xyloglucan from tamarind seed were acquired from Megazyme (Megazyme International, Bray, Co. Wicklow, Ireland). The natural substrate Sugarcane Exploded Bagasse (SEB) was kindly provided by Prof. Dr. João Atílio Jorge (University of São Paulo). Sugarcane bagasse "in natura" was provided by Prof. Dr. Delia Rita Tapia Blácido (University of São Paulo, Ribeirão Preto, Brazil). Rice straw, bean straw, barley bagasse, and corncob were provided by Prof. Dr. Maria de Lourdes Teixeira de Moraes Polizeli (University of São Paulo, Ribeirão Preto, Brazil).

\subsection{RNA Extraction, cDNA Synthesis, and Gene Amplification}

A. fumigatus mycelia were collected after growth, as described above. After freezing in liquid nitrogen and grinding into a fine powder, total RNA was isolated by using the Direct-zol ${ }^{\mathrm{TM}}$ RNA MiniPrep kit (Zymo Research, Irvine, CA, USA), according to the manufacturer's instructions. cDNA was synthesized by using SuperScript ${ }^{\circledR}$ II Reverse Transcriptase (Invitrogen, Carlsbad, CA, USA).

Specific primer sequences containing overlapping regions between the vector and the insert were employed (F: 5'-GAGAAAAGAGAGGCTGAAGCTGAATTCCAACAACCCGCCGCG-3' and R: 5'-ATCCTCTTCTGAGATGAGTTTTTGTTCTAGCAGACACTGAGAGTA-3'; overlapping sites are underlined). The amplification reaction was performed with Phusion High-Fidelity DNA Polymerase (Thermo Fisher Scientific, Waltham, MS, USA) by using the follow thermocycling conditions: $98^{\circ} \mathrm{C}$ for $30 \mathrm{~s} ; 30$ cycles of $98^{\circ} \mathrm{C}$ for $10 \mathrm{~s}, 55^{\circ} \mathrm{C}$ for $30 \mathrm{~s}$, and $72{ }^{\circ} \mathrm{C}$ for $1 \mathrm{~min}$; and $72{ }^{\circ} \mathrm{C}$ for $10 \mathrm{~min}$. The PCR product was analyzed by electrophoresis and purified from $1 \%(w / v)$ agarose gel by using the QIAquick Gel Extraction kit (Qiagen, Hilden, Germany).

\subsection{Cloning, Transformation of P. pastoris, and Screening of Recombinant Transformants}

The ORF, without predicted signal peptide, was cloned into the vector pPICZ $\alpha \mathrm{A}$ (previously digested with the restriction enzymes EcoRI and XbaI) by the Circular Polymerase Extension Cloning (CPEC) method [17]. The CPEC reaction was performed with Phusion High-Fidelity DNA Polymerase (Thermo Fisher Scientific, Waltham, MS, USA); the thermocycling conditions used were as follows: $98^{\circ} \mathrm{C}$ for $30 \mathrm{~s} ; 35$ cycles of $98^{\circ} \mathrm{C}$ for $10 \mathrm{~s}, 55^{\circ} \mathrm{C}$ for $30 \mathrm{~s}$, and $72{ }^{\circ} \mathrm{C}$ for $2 \mathrm{~min} 30 \mathrm{~s}$; and $72{ }^{\circ} \mathrm{C}$ for $10 \mathrm{~min}$. The cloning product was transformed into E. coli $\mathrm{DH} 10 \beta$, and the resistant transformants were selected by zeocin $\left(50 \mu \mathrm{g} \cdot \mathrm{mL}^{-1}\right)$. The recombinant expression vector pPICZ $\alpha \mathrm{A} / A f-e g l 7$ was linearized with the restriction enzyme PmeI and transformed into P. pastoris X-33 competent cells by electroporation, according to the EasySelect ${ }^{\mathrm{TM}}$ Pichia Expression Kit manual (Invitrogen, Carlsbad, CA, USA).

Recombinant transformants with high-level endoglucanase expression were screened in yeast extract-peptone-dextrose (YPD) plates containing $1 \%(w / v)$ low-viscosity carboxymethylcellulose (CM-Cellulose), zeocin $\left(100 \mu \mathrm{g} \cdot \mathrm{mL}^{-1}\right)$, and $1 \%(v / v)$ methanol for induction. After incubation at $30^{\circ} \mathrm{C}$ for 3 days, the plates were stained with $0.1 \%(w / v)$ Congo red solution for $20 \mathrm{~min}$ and de-stained with $1 \mathrm{M} \mathrm{NaCl}$ until pale orange hydrolysis zones appeared against an orange background (approximately $20 \mathrm{~min})$. 


\subsection{Recombinant Af-EGL7 Heterologous Expression in P. pastoris}

A single colony of recombinant $P$. pastoris X-33 harboring the vector $\mathrm{pPICZ} \alpha \mathrm{A} / A f-e g l 7$ was inoculated in buffered glycerol-complex medium (BMGY) $(2 \%(w / v)$ peptone, $1.34 \%(w / v)$ yeast nitrogen base, $1 \%(w / v)$ yeast extract, $1 \%(v / v)$ glycerol, $4 \times 10^{-5} \%(w / v)$ biotin, $100 \mathrm{mM}$ potassium phosphate buffer, $\mathrm{pH}$ 6.0) and grown at $30^{\circ} \mathrm{C}$ and $240 \mathrm{rpm}$ until the culture reached log phase growth (O.D.600nm $=2-6$ ). Then, the cells were harvested by centrifugation at $3000 \times g$ for $5 \mathrm{~min}$ and resuspended in buffered methanol-complex medium (BMMY) $(2 \%(w / v)$ peptone, $1.5 \%(v / v)$ methanol, $1.34 \%(w / v)$ yeast nitrogen base, $1 \%(w / v)$ yeast extract, $4 \times 10^{-5} \%(w / v)$ biotin, $100 \mathrm{mM}$ potassium phosphate buffer, $\mathrm{pH}$ 6.0) to an O.D.600nm $=1$. Af-EGL7 expression was induced at $30^{\circ} \mathrm{C}$ and $240 \mathrm{rpm}$ for 6 days (optimal time) under the control of the AOX1 promoter. Additional 1.5\% (v/v) final concentration methanol was added to the medium every $24 \mathrm{~h}$ to maintain the expression levels. Once the Af-egl7 gene was fused with the $\alpha$-factor signal sequence, the recombinant protein was obtained extracellularly.

\subsection{Recombinant Af-EGL7 Purification}

After 6-day culture, the culture supernatant was collected by centrifugation at $3000 \times g$ for $5 \mathrm{~min}$ and concentrated to the maximum by using an Amicon Ultra-15 Centrifugal Filter-10 kDa cutoff (Millipore, Burlington, MS, USA). Next, the concentrate was resuspended in $20 \mathrm{mM}$ sodium phosphate buffer containing $500 \mathrm{mM} \mathrm{NaCl}$ (pH 7.4) and loaded onto Ni Sepharose 6 Fast Flow resin (Ge Healthcare, Little Chalfont, United Kingdom) pre-equilibrated with the same buffer. After incubation at $4{ }^{\circ} \mathrm{C}$ for $1.5 \mathrm{~h}$ under stirring, a linear gradient from 0 to $500 \mathrm{mM}$ imidazole in $20 \mathrm{mM}$ sodium phosphate buffer containing $500 \mathrm{mM} \mathrm{NaCl}$ (pH 7.4) was applied to the column to elute the His ${ }_{6}$-tagged recombinant endoglucanase. All the fractions were collected, and protein was analyzed by $10 \%(w / v)$ SDS-PAGE, stained with Comassie Brilliant Blue R-250 (Sigma-Aldrich, St. Louis, MO, USA).

The fractions containing purified Af-EGL7 were mixed and submitted to buffer-exchange by using Amicon Ultra-15 Centrifugal Filter-10 kDa cutoff to remove excess imidazole prior to the subsequent enzymatic assays.

\subsection{Endoglucanase Activity Assay}

Af-EGL7 activity was determined by measuring reducing sugars from the reaction by the 3,5-dinitrosalicylic acid (DNS) method [41]. The enzymatic reactions were performed as described by Bernardi et al., 2018 [4]. Briefly, the reaction mixture consisting of 1\% (w/v) CM-Cellulose in $50 \mathrm{mM}$ sodium acetate buffer ( $\mathrm{pH}$ 5.0) was incubated at $55^{\circ} \mathrm{C}$ for $10 \mathrm{~min}$. The enzyme action was stopped by adding an equal volume of the DNS reagent. The mixture was boiled for $5 \mathrm{~min}$ and cooled down, and the absorbance was measured at $540 \mathrm{~nm}$. One unit of endoglucanase activity was defined as the amount of enzyme that released $1 \mu \mathrm{mol}$ of reducing sugar from the substrate per minute. Each assay was carried out in triplicate. Protein concentration was determined by the Greenberg method [18].

The effect of different $\mathrm{Cu}^{2+}$ concentrations (from 0 to $15 \mathrm{mM}$ ) on the Af-EGL7 activity was also tested. The reactions were performed as described above.

\subsection{Af-EGL7 Deglycosylation by Endo $H$}

Purified Af-EGL7 deglycosylation was accomplished by Endoglycosidase H (Endo H, New England Biolabs, Ipswich, MA, USA) in both denaturing and non-denaturing conditions, according to the manufacturer's instructions. In the first case, the recombinant protein was initially denatured at $100{ }^{\circ} \mathrm{C}$ for $10 \mathrm{~min}$. Then, the deglycosylation reaction was performed at $37^{\circ} \mathrm{C}$ for $24 \mathrm{~h}$, as described by Meleiro et al. (2017) [34]. Proteins were further analyzed by SDS-PAGE.

\subsection{Af-EGL7 Stability Assays}

Thermostability was determined by pre-incubating $0.05 \mu \mathrm{g}$ of purified Af-EGL7 in $50 \mathrm{mM}$ sodium acetate buffer ( $\mathrm{pH}$ 5.0) without substrate, at temperatures ranging from 55 to $90{ }^{\circ} \mathrm{C}$ for durations 
ranging from $30 \mathrm{~min}$ to $72 \mathrm{~h}$. The residual activities were measured under standard conditions ( $\mathrm{pH}$ 5.0, $55^{\circ} \mathrm{C}, 10 \mathrm{~min}$ ), as described in Section 3.6. The $\mathrm{pH}$ stability was estimated by measuring the residual enzymatic activity under standard conditions after incubation of the enzyme without substrate in Mcllvaine (citrate-phosphate) buffers $\mathrm{pH} 3.0-8.0$ at $4{ }^{\circ} \mathrm{C}$ for up to $72 \mathrm{~h}$ [4].

\subsection{Determination of Kinetic Parameters}

The Af-EGL7 kinetic parameters $\left(\mathrm{K}_{\mathrm{M}}, \mathrm{V}_{\max }\right.$, and $\left.\mathrm{k}_{\mathrm{cat}}\right)$ were determined when CM-Cellulose (2.5-30 mg. $\left.\mathrm{mL}^{-1}\right), \beta$-glucan $\left(0.5-15 \mathrm{mg} \cdot \mathrm{mL}^{-1}\right)$, or xyloglucan $\left(1.0-8.5 \mathrm{mg} \cdot \mathrm{mL}^{-1}\right)$ were used as substrates. The reactions were performed in $50 \mathrm{mM}$ sodium acetate buffer ( $\mathrm{pH}$ 5.0) as previously described. The parameters were calculated by linear regression, by using the Lineweaver-Burk graphical method.

\subsection{Glucose and Cellobiose Effect on Af-EGL7 Activity}

The glucose and cellobiose effect on Af-EGL7 activity was determined in the presence of increasing concentrations $(0.5-50 \mathrm{mM})$ of both sugars by using the chromogenic substrate Azo-Xyloglucan from Tamarind (Megazyme International, Bray, Co. Wicklow, Ireland). The enzymatic assays were performed in $85 \mathrm{mM}$ sodium acetate buffer ( $\mathrm{pH} 4.5)$ at $40{ }^{\circ} \mathrm{C}$ for $10 \mathrm{~min}$, according to the manufacturer's instructions, with slight modifications. The reactions were stopped by adding 1.7 volumes of absolute ethanol. The supernatants were harvested by centrifugation at $1000 \times g$ for $10 \mathrm{~min}$, and the absorbances were measured at $590 \mathrm{~nm}$. Enzyme activity without glucose or cellobiose addition was considered 100\%.

\subsection{Lignocellulosic Biomass saccharification}

Lignocellulose enzymatic hydrolysis was carried out as described previously by Bernardi et al. (2018) with some modifications [4]. The saccharification was accomplished in $50 \mathrm{mM}$ sodium acetate buffer ( $\mathrm{pH} 5.0)$ containing $1 \%(w / v)$ of one of the following biomasses: sugarcane bagasse "in natura", $\mathrm{SEB}$, rice straw, corncob, barley bagasse, or bean straw.

The reactions consisted of 0.009 FPU Celluclast ${ }^{\circledR}$ 1.5L (Sigma-Aldrich, St. Louis, MO, USA) and $10 \mu \mathrm{g}$ of Af-EGL7, added per $10 \mathrm{mg}$ of each biomass. The reactions were conducted at $55^{\circ} \mathrm{C}$ and $1000 \mathrm{rpm}$ for up to $72 \mathrm{~h}$ in a final volume of $1 \mathrm{~mL}$. DNS was added to stop the reactions and to measure the released reducing sugars. Control experiments were conducted in the same way, in the absence of Af-EGL7. The reported results represent the means \pm SD calculated from at least three experimental replicates.

\subsection{Statistical Analysis}

Data are expressed as the mean of replicates \pm SD. Significant differences between the treatment groups were analyzed by using Tukey's test (significance, $p<0.05$ ).

\subsection{Reproducibility of the Results}

All the data are the mean of at least three independent experiments and show consistent results.

\section{Conclusions}

At the industrial level, it is essential that enzymes maintain their activity at high temperatures and high $\mathrm{pH}$ values. This study has shown a GH7 endoglucanase with favorable properties for industrial applications, such as high thermal and pH stabilities. In addition, Af-EGL7 can be considered as a good hydrolytic enzyme that can improve biomass degradation by Celluclast ${ }^{\circledR}$ 1.5L. Besides that, Af-EGL7 is a glucose-cellobiose-tolerant endoglucanase. All these properties make Af-EGL7 an important candidate for application in the improvement of commercial cocktails used in second-generation biofuel production as well as in other biorefinary processes.

Supplementary Materials: Supplementary materials can be found at http://www.mdpi.com/1422-0067/20/9/2261/s1. 
Author Contributions: Conceptualization, A.V.B. and T.M.D.; data curation, A.V.B and D.K.Y.; formal analysis, A.V.B; methodology, A.V.B. and D.K.Y.; supervision, S.A.U and T.M.D.; writing (Review and Editing), A.V.B., S.A.U, and T.M.D.; project Administration, T.M.D.; funding Acquisition, T.M.D.

Funding: This research was funded by Fundação de Amparo à Pesquisa do Estado de São Paulo (FAPESP, 2014/10466-0) and Conselho Nacional de Desenvolvimento Científico e Tecnológico (CNPq: 425465/2016-0). AVB was funded by a scholarship granted by Coordenação de Aperfeiçoamento de Pessoal de Nível Superior - Brasil (CAPES), Finance Code 001. DKY was funded by a scholarship granted by Fundação de Amparo à Pesquisa do Estado de São Paulo (FAPESP, 2018/11231-7).

Conflicts of Interest: The authors declare no conflicts of interest. The funders had no role in the design of the study; in the collection, analyses, or interpretation of data; in the writing of the manuscript, or in the decision to publish the results.

\section{References}

1. Jain, K.K.; Kumar, S.; Bhardwaj, K.N.; Kuhad, R.C. Functional Expression of a Thermostable Endoglucanase from Thermoascus aurantiacus RCKK in Pichia pastoris X-33 and Its Characterization. Mol. Biotechnol. 2018, 60, 736-748. [CrossRef] [PubMed]

2. Silva, T.P.; de Albuquerque, F.S.; dos Santos, C.W.V.; Franco, M.; Caetano, L.C.; Pereira, H.J.V. Production, purification, characterization and application of a new halotolerant and thermostable endoglucanase of Botrytis ricini URM 5627. Bioresour. Technol. 2018, 270, 263-269. [CrossRef]

3. Ramos, J.L.; Duque, E. Twenty-first-century chemical odyssey: Fuels versus commodities and cell factories versus chemical plants. Microb. Biotechnol. 2019, 12, 200-209. [CrossRef] [PubMed]

4. Bernardi, A.V.; De Gouvêa, P.F.; Gerolamo, L.E.; Yonamine, D.K.; De Lourdes, L.; Balico, D.L.; Uyemura, S.A. Functional characterization of GH7 endo-1,4- $\beta$-glucanase from Aspergillus fumigatus and its potential industrial application. Protein Expr. Purif. 2018, 150, 1-11. [CrossRef] [PubMed]

5. Hua, C.; Li, W.; Han, W.; Wang, Q.; Bi, P.; Han, C.; Zhu, L. Characterization of a novel thermostable GH7 endoglucanase from Chaetomium thermophilum capable of xylan hydrolysis. Int. J. Biol. Macromol. 2018, 117, 342-349. [CrossRef]

6. Rigoldi, F.; Donini, S.; Redaelli, A.; Parisini, E.; Gautieri, A. Review: Engineering of thermostable enzymes for industrial applications. APL Bioeng. 2018, 2. [CrossRef]

7. de Gouvêa, P.F.; Bernardi, A.V.; Gerolamo, L.E.; Santos, E.S.; Riano-Pachon, D.; Uyemura, S.A.; Dinamarco, T.M. Transcriptome and secretome analysis of Aspergillus fumigatus in the presence of sugarcane bagasse. BMC Genomics 2018, 19, 1-18. [CrossRef] [PubMed]

8. Aich, S.; Singh, R.K.; Kundu, P.; Pandey, S.P.; Datta, S. Genome-wide characterization of cellulases from the hemi-biotrophic plant pathogen, Bipolaris sorokiniana, reveals the presence of a highly stable GH7 endoglucanase. Biotechnol. Biofuels 2017, 10,1-14. [CrossRef]

9. Liu, Y.; Dun, B.; Shi, P.; Ma, R.; Luo, H.; Bai, Y.; Xie, X.; Yao, B. A novel GH7 Endo- $\beta-1$,4-glucanase from Neosartorya fischeri P1 with good thermostability, broad substrate specificity and potential application in the brewing industry. PLOS ONE 2015, 10, e0137485. [CrossRef]

10. Berto, G.L.; Velasco, J.; Tasso Cabos Ribeiro, C.; Zanphorlin, L.M.; Noronha Domingues, M.; Tyago Murakami, M.; Polikarpov, I.; de Oliveira, L.C.; Ferraz, A.; Segato, F. Functional characterization and comparative analysis of two heterologous endoglucanases from diverging subfamilies of glycosyl hydrolase family 45. Enzyme Microb. Technol. 2019, 120, 23-35. [CrossRef]

11. Karnaouri, A.C.; Topakas, E.; Christakopoulos, P. Cloning, expression, and characterization of a thermostable GH7 endoglucanase from Myceliophthora thermophila capable of high-consistency enzymatic liquefaction. Appl. Microbiol. Biotechnol. 2014, 98, 231-242. [CrossRef]

12. Pellegrini, V.O.A.; Serpa, V.I.; Godoy, A.S.; Camilo, C.M.; Bernardes, A.; Rezende, C.A.; Junior, N.P.; Franco Cairo, J.P.L.; Squina, F.M.; Polikarpov, I. Recombinant Trichoderma harzianum endoglucanase I (Cel7B) is a highly acidic and promiscuous carbohydrate-active enzyme. Appl. Microbiol. Biotechnol. 2015, 99, 9591-9604. [CrossRef]

13. Moroz, O.V.; Maranta, M.; Shaghasi, T.; Harris, P.V.; Wilson, K.S.; Davies, G.J. The three-dimensional structure of the cellobiohydrolase Cel7A from Aspergillus fumigatus at $1.5 \AA$ Aesolution. Acta Crystallogr. Sect. FStructural Biol. Commun. 2015, 71, 114-120. [CrossRef] 
14. Miao, J.; Li, T.; Ma, L.; Liu, D.; Shen, Q.; Wang, M.; Huang, Q. Effects of amino acids on the lignocellulose degradation by Aspergillus fumigatus Z5: Insights into performance, transcriptional, and proteomic profiles. Biotechnol. Biofuels 2019, 12, 1-19. [CrossRef]

15. Chahed, H.; Boumaiza, M.; Ezzine, A.; Marzouki, M.N. Heterologous expression and biochemical characterization of a novel thermostable Sclerotinia sclerotiorum GH45 endoglucanase in Pichia pastoris. Int. J. Biol. Macromol. 2018, 106, 629-635. [CrossRef]

16. Akbarzadeh, A.; Ranaei Siadat, S.O.; Motallebi, M.; Zamani, M.R.; Barshan Tashnizi, M.; Moshtaghi, S. Characterization and high level expression of acidic endoglucanase in Pichia pastoris. Appl. Biochem. Biotechnol. 2014, 172, 2253-2265. [CrossRef]

17. Quan, J.; Tian, J. Circular polymerase extension cloning for high-throughput cloning of complex and combinatorial DNA libraries. Nat. Protoc. 2011, 6, 242-251. [CrossRef]

18. David, B.Y. The colorimetric determination of the serum proteins. J. Biol. Chem. 1929, 82, 545-550.

19. Hamilton, S.R.; Gerngross, T.U. Glycosylation engineering in yeast: The advent of fully humanized yeast. Curr. Opin. Biotechnol. 2007, 18, 387-392. [CrossRef]

20. Amore, A.; Knott, B.C.; Supekar, N.T.; Shajahan, A.; Azadi, P.; Zhao, P.; Wells, L.; Linger, J.G.; Hobdey, S.E.; Vander Wall, T.A.; et al. Distinct roles of N- and O-glycans in cellulase activity and stability. Proc. Natl. Acad. Sci. USA 2017, 114, 13667-13672. [CrossRef]

21. Wang, J.; Wang, J.; Gao, G.; Li, Y.; Yang, L.; Liang, Y.; Jin, H.; Han, W.; Feng, Y.; Zhang, Z. Cloning, expression, and characterization of a thermophilic endoglucanase, AcCel12B from Acidothermus cellulolyticus 11B. Int. J. Mol. Sci. 2015, 16, 25080-25095. [CrossRef] [PubMed]

22. Narra, M.; Dixit, G.; Divecha, J.; Kumar, K.; Madamwar, D.; Shah, A.R. Production, purification and characterization of a novel GH 12 family endoglucanase from Aspergillus terreus and its application in enzymatic degradation of delignified rice straw. Int. Biodeterior. Biodegrad. 2014, 88, 150-161. [CrossRef]

23. Valenzuela, S.V.; Valls, C.; Schink, V.; Sánchez, D.; Roncero, M.B.; Diaz, P.; Martínez, J.; Pastor, F.I.J. Differential activity of lytic polysaccharide monooxygenases on celluloses of different crystallinity. Effectiveness in the sustainable production of cellulose nanofibrils. Carbohydr. Polym. 2019, 207, 59-67. [CrossRef] [PubMed]

24. Rubio, M.V.; Zubieta, M.P.; Franco Cairo, J.P.L.; Calzado, F.; Paes Leme, A.F.; Squina, F.M.; Prade, R.A.; De Lima Damásio, A.R. Mapping N-linked glycosylation of carbohydrate-active enzymes in the secretome of Aspergillus nidulans grown on lignocellulose. Biotechnol. Biofuels 2016, 9, 1-19. [CrossRef] [PubMed]

25. Wang, J.; Kang, L.; Liu, Z.; Yuan, S. Gene cloning, heterologous expression and characterization of a Coprinopsis cinerea endo- $\beta-1,3(4)$-glucanase. Fungal Biol. 2017, 121, 61-68. [CrossRef]

26. Patel, A.K.; Singhania, R.R.; Sim, S.J.; Pandey, A. Thermostable cellulases: Current status and perspectives. Bioresour. Technol. 2019, 279, 385-392. [CrossRef] [PubMed]

27. Wang, K.; Luo, H.; Shi, P.; Huang, H.; Bai, Y.; Yao, B. A highly-active endo-1,3-1,4- $\beta$-glucanase from thermophilic Talaromyces emersonii CBS394.64 with application potential in the brewing and feed industries. Process Biochem. 2014, 49, 1448-1456. [CrossRef]

28. Mohd Azhar, S.H.; Abdulla, R.; Jambo, S.A.; Marbawi, H.; Gansau, J.A.; Mohd Faik, A.A.; Rodrigues, K.F. Yeasts in sustainable bioethanol production: A review. Biochem. Biophys. Reports. 2017, 10, 52-61. [CrossRef]

29. Azizi, M.; Hemmat, J.; Seifati, S.M.; Torktaz, I.; Karimi, S. Characterization of a thermostable endoglucanase produced by Isoptericola variabilis sp. IDAH9. Brazilian J. Microbiol. 2015, 46, 1225-1234. [CrossRef]

30. Brodeur, G.; Yau, E.; Badal, K.; Collier, J.; Ramachandran, K.B.; Ramakrishnan, S. Chemical and physicochemical pretreatment of lignocellulosic biomass: A review. Enzyme Res. 2011, 2011, 1-17. [CrossRef]

31. Kumar, P.; Barrett, D.M.; Delwiche, M.J.; Stroeve, P. Methods for pretreatment of lignocellulosic biomass for efficient hydrolysis and biofuel production. Ind. Eng. Chem. Res. 2009, 48, 3713-3729. [CrossRef]

32. Zhao, J.; Shi, P.; Yuan, T.; Huang, H.; Li, Z.; Meng, K.; Yang, P.; Yao, B. Purification, gene cloning and characterization of an acidic $\beta$-1,4-glucanase from Phialophora sp. G5 with potential applications in the brewing and feed industries. J. Biosci. Bioeng. 2012, 114, 379-384. [CrossRef]

33. Luo, H.; Yang, J.; Li, J.; Shi, P.; Huang, H.; Bai, Y.; Fan, Y.; Yao, B. Molecular cloning and characterization of the novel acidic xylanase XYLD from Bispora sp. MEY-1 that is homologous to family 30 glycosyl hydrolases. Appl. Microbiol. Biotechnol. 2010, 86, 1829-1839. [CrossRef] [PubMed]

34. Meleiro, L.P.; Carli, S.; Fonseca-Maldonado, R.; da Silva Torricillas, M.; Zimbardi, A.L.R.L.; Ward, R.J.; Jorge, J.A.; Furriel, R.P.M. Overexpression of a Cellobiose-Glucose-Halotolerant Endoglucanase from Scytalidium thermophilum. Appl. Biochem. Biotechnol. 2017, 1-18. [CrossRef] [PubMed] 
35. Pei, J.; Pang, Q.; Zhao, L.; Fan, S.; Shi, H. Thermoanaerobacterium thermosaccharolyticum $\beta$-glucosidase: A glucose-tolerant enzyme with high specific activity for cellobiose. Biotechnol. Biofuels 2012, 5, 1-10. [CrossRef]

36. Andrić, P.; Meyer, A.S.; Jensen, P.A.; Dam-Johansen, K. Reactor design for minimizing product inhibition during enzymatic lignocellulose hydrolysis: I. Significance and mechanism of cellobiose and glucose inhibition on cellulolytic enzymes. Biotechnol. Adv. 2010, 28, 308-324. [CrossRef] [PubMed]

37. Kim, M.; Day, D.F. Composition of sugarcane, energy cane, and sweet sorghum suitable for ethanol production at Louisiana sugar mills. J. Ind. Microbiol. Biotechnol. 2011, 38, 803-807. [CrossRef]

38. Prassad, S.; Singh, A.; Joshi, H.C. Ethanol as an alternative fuel from agricultural, industrial and urban residues. Res. Conserv. Recycl. 2007, 50,1-39. [CrossRef]

39. Mello, L.R.P.F.; Mali, S. Use of malt bagasse to produce biodegradable baked foams made from cassava starch. Ind. Crops Prod. 2014, 55, 187-193. [CrossRef]

40. Brum, S.S.; de Oliveira, L.C.A.; Bianchi, M.L.; Guerreiro, M.C.; de Oliveira, L.K.; Carvalho, K.T.G. Síntese de acetato de celulose a partir da palha de feijão utilizando $N$-bromossuccinimida (NBS) como catalisador. Polímeros 2012, 22, 447-452. [CrossRef]

41. Miller, G.L. Use of Dinitrosalicylic Acid Reagent for Determination of Reducing Sugar. Anal. Chem. 1959, 31, 426-428. [CrossRef]

(C) 2019 by the authors. Licensee MDPI, Basel, Switzerland. This article is an open access article distributed under the terms and conditions of the Creative Commons Attribution (CC BY) license (http://creativecommons.org/licenses/by/4.0/). 